\title{
Crop coefficient of cut gerbera with water supplementation in a protected environment
}

\author{
Jéssica Dariane Piroli ${ }^{1} \oplus$, Marcia Xavier Peiter ${ }^{1} \oplus$, Adroaldo Dias Robaina ${ }^{1} \oplus$, Marcelo Antonio Rodrigues ${ }^{1} \oplus$,

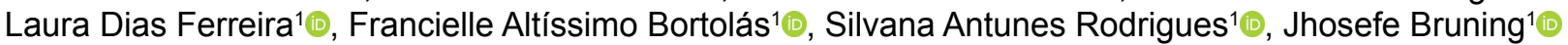

\footnotetext{
1 Universidade Federal de Santa Maria, Departamento de Engenharia Rural, Santa Maria-RS, Brazil. E-mail: jehpiroli@hotmail.com; mpeiter@gmail.com; diasrobaina@gmail.com; marceloarodrigues2002@yahoo.com.br; lauradiasferreira14@gmail.com; fbortolas@gmail.com; rodrigues.silvana.a@gmail.com; jhosefe.b@gmail.com
}

ABSTRACT: The determination of the crop coefficient $(\mathrm{Kc})$ is vital since, although gerbera cultivation is constantly expanding, there is little research on the evapotranspiration of the crop cultivated under a protected environment to obtain the correct irrigation management. The objective of this work was to evaluate the evapotranspiration and crop coefficients of cut gerbera, cultivated in protected environment. The reference evapotranspiration (ETo) and crop evapotranspiration (ETc) were obtained through the Penman and weighing lysimetry methods, respectively. The experimental design used was completely randomized, consisting of five irrigation treatments $(120,100,80,60$, and $40 \%$ of the water retention capacity), with ten replicates each, totalizing 50 experimental units. The $\mathrm{Kc}$ was evaluated using the irrigation lamina that presented the highest production of floral stems among the tested treatments, obtained through the relation between ETc and ETo. The mean of the crop coefficient ranged from 0.72 in vegetative period I, 0.81 in vegetative period II, 0.85 in flowering I, 0.89 in full flowering II, 1.33 in full flowering III, and 1.06 in end of the flowering I. The water consumption for the cut gerbera crop in the treatments with water availability ranged from 225.87 to $523.58 \mathrm{~mm}$. Therefore, the crop coefficients proposed for the different phenological stages of the gerbera were efficient for irrigation management.

\section{Coeficiente de cultura da gérbera de corte com suplementação hídrica em ambiente protegido}

RESUMO: A determinação do coeficiente de cultivo $(\mathrm{Kc})$ de uma cultura é de fundamental importância, pois apesar do cultivo de gérbera estar em constante expansão, as pesquisas referentes a evapotranspiração da cultura na condição de ambiente protegido para o correto manejo da irrigação ainda são escassos. Objetivo deste estudo foi determinar a evapotranspiração e o Kc para a gérbera de corte cultivada em ambiente protegido. A evapotranspiração de referência (ETo) e a evapotranspiração da cultura $(E T c)$ foram obtidas através dos métodos de Penman e lisimetria de pesagem, respectivamente. 0 delineamento experimental utilizado foi o inteiramente casualizado, composto por cinco tratamentos de irrigação $(120,100,80,60$ e $40 \%$ da capacidade de retenção de água), com dez repetições cada, totalizando cinquenta unidades experimentais. Para a avaliação do Kc foi foi utilizada a lamina de irrigação que apresentou a maior produção de hastes florais entre os tratamentos testados, sendo obtido através da relação entre a ETc e a ETo. A média do coeficiente de cultura variou de 0,72 para o período vegetativo I, 0,81 para o periodo vegetativo II, 0,85 para o florescimento I, 0,89 para pleno florescimento II, 1,33 para o pleno florescimento III e 1,06 para queda do florescimento I. O consumo hídrico para a cultura da gérbera de corte nos tratamentos com limite de disponibilidade hídrica variou de 225,87 a $523,58 \mathrm{~mm}$. Portanto, os coeficientes de cultivo propostos para os diferentes estágios fenológicos das gerberas foram eficientes no manejo da irrigação.

Palavras-chave: evapotranspiração; Gerbera jamesonii; manejo de irrigação 


\section{Introduction}

Floriculture is one of the main segments of Brazilian agribusiness, characterizing an expanding agricultural activity (Girardi et al., 2016). The proportion of cut flowers increases each year, followed by live plants, bulbs, and foliage (Landgraf \& Paiva, 2009). Moreover, this branch is considered highly profitable and generates jobs, especially in countries that have ideal production climates and low production and labor costs (Morales-Perez et al., 2014).

The Gerbera ( $G$. jamesonii L. ) is one of the most important ornamental species for the cut flowers sector (Cardoso \& Imthurn, 2018), and is traditionally known for its variety of colors and shapes (Bashandy et al., 2015). The flower is among the most commercialized cut flowers in the national market and its beauty causes consumer acceptance (Menegaes et al., 2015; Sulzbach et al., 2015).

Cultivation in a protected environment presents several advantages when compared to open cultivation since it provides through temperature control, humidity, water availability and $\mathrm{CO}_{2}$, greater physiological comfort to the crop and helps to ensure better plant quality and productivity (Carvalho et al., 2018). The correct irrigation management and the monitoring of climatic variables are essential in this cultivation technique, in which the only source of water is supplied from irrigation (Holcman et al., 2015; Girardi et al., 2016).

In ornamental species cultivated in the substrate, water availability requires the correct irrigation management but the quantification of water through water balance is difficult to perform (Girardi et al., 2016). In this sense, most soil moisture sensors have no adhesion to porous substrates, such as water peat, therefore, it is necessary to assess management methodologies through climatic elements under these conditions.
Doorenbos \& Pruitt (1977) suggest the relation of the water consumption of a crop based on the product between the reference evapotranspiration measured cultivating conditions and the crop coefficient. These coefficients must be quantified in function of the phenological stage of the crop, with values ranging according to the crop and its development stage, differing by location and climate in which they are evaluated (Barbosa et al., 2015). The knowledge of this coefficient allows us to maximize water use and is an important tool to design irrigation projects (Ribeiro et al., 2009; Netto et al., 2011).

In this sense, the relevance of this study is justified by the scarcity of information regarding the crop coefficient for gerbera in the southern region of Brazil, thus requiring research concerning its development. In view of the above, the objective of this work was to evaluate the evapotranspiration and crop coefficients of cut gerbera, cultivated in protected environment

\section{Materials and Methods}

\section{Plant material and cultivation}

The present work was carried out in the experimental area of the Floriculture Sector of the Polytechnic College, Federal University of Santa Maria, Santa Maria - RS, Brazil (2943'23"S and 5343'15"W, an altitude of $95 \mathrm{~m}$ ). The period of the experiment was from November 2016 to May 2017. The experiment was carried out in a $600 \mathrm{~m}^{2}(20 \times 30 \mathrm{~m})$ greenhouse with a ceiling height of $3,5 \mathrm{~m}$, with 150 micron plastic cover with PadFan cooling system and hot air heating.

The study region presents a Cfa climate - subtropical humid, with undefined dry season according to the Köppen climatic classification. The temperatures normally range from $10 \circ \mathrm{C}$ to 31 으 $\mathrm{C}$ throughout the year, with an average relative humidity of $74.4 \%$, are presented in Figure 1.

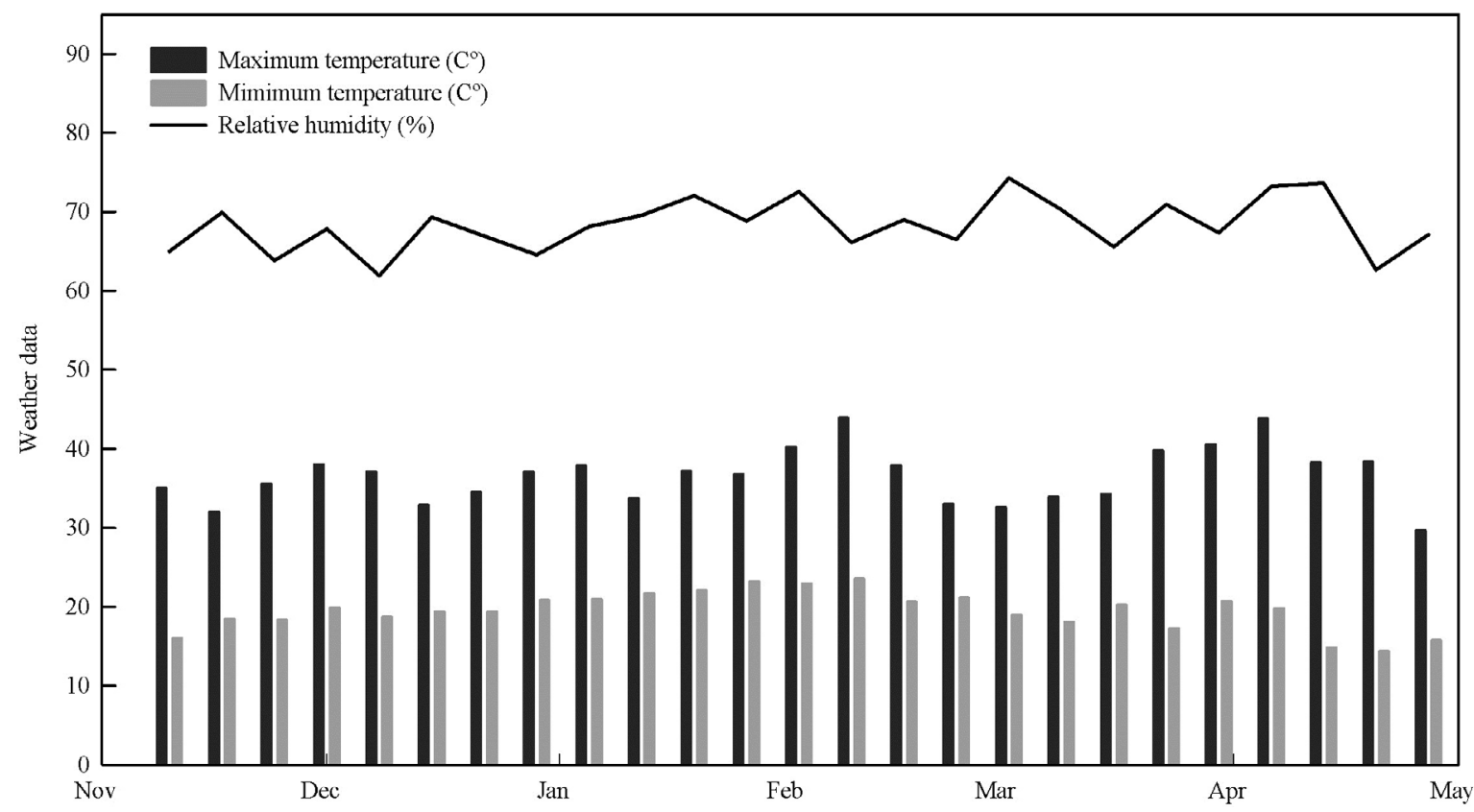

Figure 1. Data air temperature (maximum and minimum) and relative humidity throughout the experiment. 
Gerbera (G. jamesonii L) seedlings were acquired from the Uniplant company located in Holambra/SP, using the Caribá variety, which has red flowers. The seedlings were transplanted on November 3, 2016 We used stiff polyethylene pots with a capacity of 25 liters and drains in the lower end.

\section{Substrate used and physical characteristics}

The substrate used was water peat (WP), transplanting a seedling to each pot, characterized as an experimental unit.

Was placed $100 \%$ of water peat (WP) in all pots. The physical characteristics of the substrate used are presented in Table 1.

The density represents the relationship between mass and volume of the substrate and, in general, is used as a determining evaluation parameter since the wet density can vary according to the amount of water in the sample during the analysis. Normally, the reference values of dry density for substrates range from 350 to $500 \mathrm{~kg} \mathrm{~m}^{-3}$ (Conover, 1967). However, this value was slightly below the indicated for water peat, which can be explained by the influence of the density determination method and initial moisture content of the sample (Fermino \& Kämpf, 2012).

According to Verdonck \& Gabriels (1988), the ideal total porosity for substrates should be between 80 and $90 \%$. Therefore, we observed that the content was within the ideal range in the substrate evaluated. These authors also suggest the ideal values between 10 and $15 \%$ for the aeration space (AS). However, the values obtained for the substrates were superior to this range. High values of AS can lead to water deficiency in plants, especially when irrigations are infrequent (Zorzeto et al., 2014).

The ideal values of available water occur between 25 and 35\% (De Boodt \& Verdonck, 1972; Cattivello, 1991; Schafer et al., 2008), which is the case of the values found for the peat. Table 2 presents the $\mathrm{pH}$, electrical conductivity (EC), readily available water (RAW), buffer water (BW), and remaining water (RW).

The $\mathrm{pH}$ value is of 6.50 for which, according to Fermino (2014), is within the range of ideal values for the cultivation of most plants, which is between 5.5 and $6.5\left(\mathrm{pH}\right.$ in $\left.\mathrm{H}_{2} \mathrm{O}\right)$. The $\mathrm{pH}$ is considered extremely relevant plant growth and development and can directly affect nutrient availability and compromise the production and quality of the final product (Ludwig et al., 2015).

The electrical conductivity value obtained was of $0.78 \mathrm{~ms}$ $\mathrm{cm}^{-1}$, which is above the ideal range $\left(0.36-0.65 \mathrm{mS} \mathrm{cm}^{-1}\right)$. High content of salt in the soil or substrate may negatively influence plant growth and development.
For Schmitz et al. (2002), the content of readily available water considered as ideal is between 20 and $30 \%$, while for buffering water, which represents retained water, the ideal is of approximately $5 \%$. Although the remaining water is not available to most plants, its main relevance is its influence on substrate properties, such as electrical conductivity, thermal capacity, and hydraulic conductivity, which are considered as ideal with values from 20 to 30\% (Schafer et al., 2015). The highest water retention capacity of the substrate occurred at the lowest water column pressure ( $10 \%$ of WRC).

This information may demonstrate a greater water availability for the plant, making it easier to remove water from the substrate.

\section{Experimental design}

We used a completely randomized experimental design with five treatments, which were $120 \%, 100 \%, 80 \%, 60 \%$, and $40 \%$ of the water retation capacity (WRC) of the pot, and 10 replicates for each treatment, totalizing 50 pots for experimental units.

\section{Determination of water retaining capacity of the pot}

We determined the WRC according to the methodology described by Kämpf et al. (2006), for which we used the Equation 1, adapted by Schwab et al. (2013).

$$
\mathrm{PV} \%=\left(\mathrm{PV}_{\mathrm{CRA}}=\mathrm{PV}_{\text {seco }}\right) \cdot \%+\mathrm{PV}_{\text {seco }}
$$

in which: PV\% - weight of the pot for each treatment; $\mathrm{PV}_{\mathrm{CRA}}-$ water-retaining capacity; $\mathrm{PV}_{\text {seco }}$ - weight of the pot filled with completely dry substrate.

The amount of water stored in the substrate was determined using the water balance method, counting the water inputs and outputs of the pot. The only water input was through irrigation, given that the experiment was conducted in a protected environment and in pots. The crop evapotranspiration (ETc) was evaluated by weighing lysimetry.

Irrigation was done manually with a seven-day irrigation shift and the reference evapotranspiration (ETo) was calculated using the Penman method (1948). Gerbera flower stalks were harvested daily, whenever new stems were at the point of harvest, this is, when there were one to three flower circles (crown flowers) visibly open.

It was installed a digital thermo-hygrometer inside the greenhouse to check the maximum and minimum temperatures and relative humidity of the air. The readings were performed daily in an interval of 15 minutes, as shown in Figure 1. Other data such as insolation and solar radiation

Table 1. Physical characteristics of the Water Peat (WP) used as a substrate in the production of gérberas. Santa Maria.

\begin{tabular}{|c|c|c|c|c|c|c|c|c|c|}
\hline \multirow[t]{2}{*}{ Substrate } & \multirow{2}{*}{$\begin{array}{l}\mathrm{pH}\left(\mathrm{H}_{2} \mathrm{O}\right) \\
1: 5\left(\mathrm{v} \mathrm{v}^{-1}\right)\end{array}$} & \multirow{2}{*}{$\begin{array}{c}\mathrm{EC} \\
\left(\mathrm{mS} \mathrm{cm} \mathrm{cm}^{-1}\right)\end{array}$} & RAW & BW & \multirow[t]{2}{*}{ RW } & \multirow{2}{*}{$\begin{array}{c}\text { Density (DD) } \\
\left(\mathrm{kg} \mathrm{m}^{-3}\right)\end{array}$} & $\begin{array}{c}\text { Total } \\
\text { porosity (TP) }\end{array}$ & $\begin{array}{c}\text { Aeration } \\
\text { space (AS) } \\
\end{array}$ & $\begin{array}{c}\text { Available } \\
\text { water (AW) }\end{array}$ \\
\hline & & & & $(\%)$ & & & \multicolumn{3}{|c|}{$(\%)$} \\
\hline WP & 6.5 & 0.78 & 30.27 & 3.54 & 38.63 & 257.36 & 88.46 & 16.03 & 33.81 \\
\hline
\end{tabular}

$\mathrm{DD}=$ dry density; $\mathrm{TP}=$ total porosity; $\mathrm{AS}=$ aeration space; $\mathrm{AW}=$ available water; $\mathrm{pH}=$ determined in water, 1:5 (v/v) dilution; $\mathrm{EC}=$ electric conductivity obtained in solution 1:5 ( $\mathrm{v} / \mathrm{v}$ ); RAW = readily available water; $\mathrm{BW}=$ buffering water; $\mathrm{RW}=$ remaining water. 
were obtained from the Automatic Station of the Instituto Nacional de Meteorologia (INMET), located near the Federal University of Santa Maria.

\section{Determination of the crop coefficient}

The crop coefficient $(\mathrm{Kc})$ was calculated for each day of the crop cycle based on the ETc estimated by lysimetry and ETo estimated by Penman, according to Equation 2 .

$$
\mathrm{Kc}=\frac{\text { Etc }}{\text { Eto }}
$$

in which: Kc - crop coefficient; Etc - crop evapotranspiration $\left(\mathrm{mm}\right.$ day $\left.^{-1}\right)$; Eto - reference evapotranspiration $\left(\mathrm{mm} \mathrm{day}^{-1}\right)$.

Thus, to determine the crop coefficient of cut gerbera was used the irrigation dephts that presented the highest production of floral stems among the treatments tested.

\section{Statistical analysis}

The statistical program used for the analysis was SISVAR 5.6. The comparison of the production component (number of flower stems) among the applied treatments was performed through analysis of variance (ANOVA) at a level of $5 \%$ of significance, for which we performed a regression analysis if a statistical significance occurred.

\section{Results and Discussion}

Accumulated evapotranspiration and number of stems produced

The number of stems presented significant difference for the irrigation depths tested, as can be observed in Table 2 .

The production of floral stems and the accumulated evapotranspiration of the cut gerbera in the different tested irrigation levels can be seen in Figures 1 and 2. When analyzing the results obtained, was verified lower and higher water consumption, respectively, in the treatments with levels considered deficit and excessive ( 40 and $120 \%$ of WRC), and a lower number of floral stems regarding the other levels tested.

It is important to emphasize that adequate relation between plant height and stem diameter and the diameter of the inflorescence influence the quality of the flower stems of the cut gerbera since tall and thin stems tend to present

Tabela 2. Variance analysis for production of cut gerbera flower stem under different irrigation levels.

\begin{tabular}{ccccccc}
\hline $\begin{array}{c}\text { Variation } \\
\text { sources }\end{array}$ & $\begin{array}{c}\text { Degrees } \\
\text { of } \\
\text { freedom } \\
\text { (d.f) }\end{array}$ & $\begin{array}{c}\text { Sum of } \\
\text { square } \\
\text { (SQ) }\end{array}$ & $\begin{array}{c}\text { Mean } \\
\text { square } \\
\text { (QM) }\end{array}$ & F value & Prob>F \\
\hline Treatment & 4 & 321.720 & 80.430 & 91.629 & $0.000^{*}$ \\
Error & 45 & 39.500 & 0.8877 & & \\
Total & 49 & 361.220 & & & \\
Mean & 7.34 & & & & \\
CV (\%) & 12.76 & & & & \\
\hline
\end{tabular}

*Significant at $5 \%$ probability by $\mathrm{F}$ test, $\mathrm{CV}$ - Coefficient of variation.

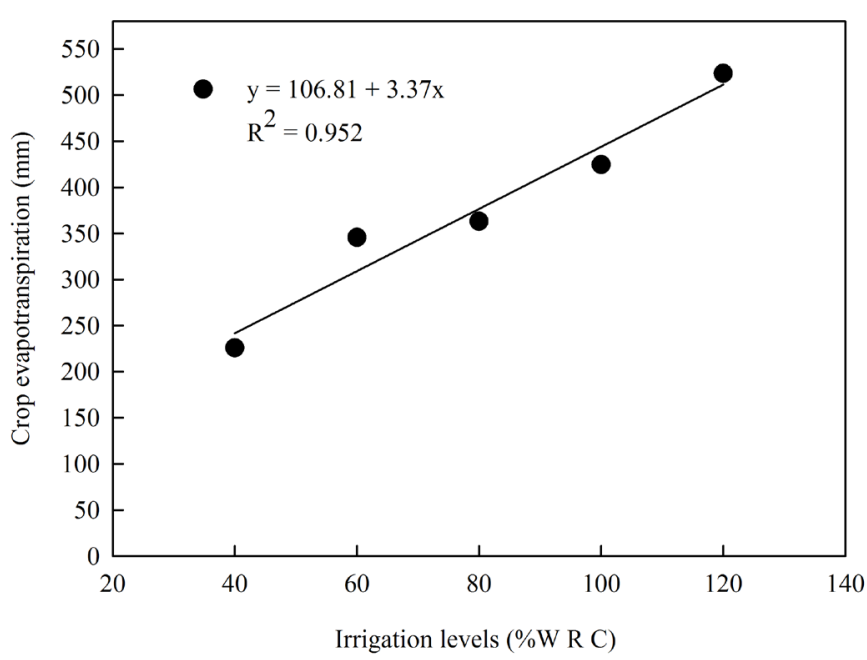

Figure 2. Accumulated evapotranspiration (ETc) throughout the gerbera crop cycle in the different irrigation levels.

reduced support. These factors can be heightened as adequate cultural practices, including the correct management of water availability.

De Souza Ferraz et al. (2012) reported that plants submitted to water deficit probably paralyze growth and development, and close the stomata, leading to a decrease in water consumption and production. In the same way, the level with greater water consumption presented a higher crop evapotranspiration, resulting in a higher water replenishment when compared to the other treatments, negatively influencing the quality and production of the floral stems of the cut gerbera, causing symptoms similar to the water deficit in addition to a reduced photosynthesis and growth, as well as wilting. The results obtained are attributed to both the lack and excess of since the higher water consumption does not necessarily imply greater production or development.

Collaborating with the results found in this work, Girardi et al. (2016) conducted an experiment with the alstroemeria culture under protected environment condition, submitting

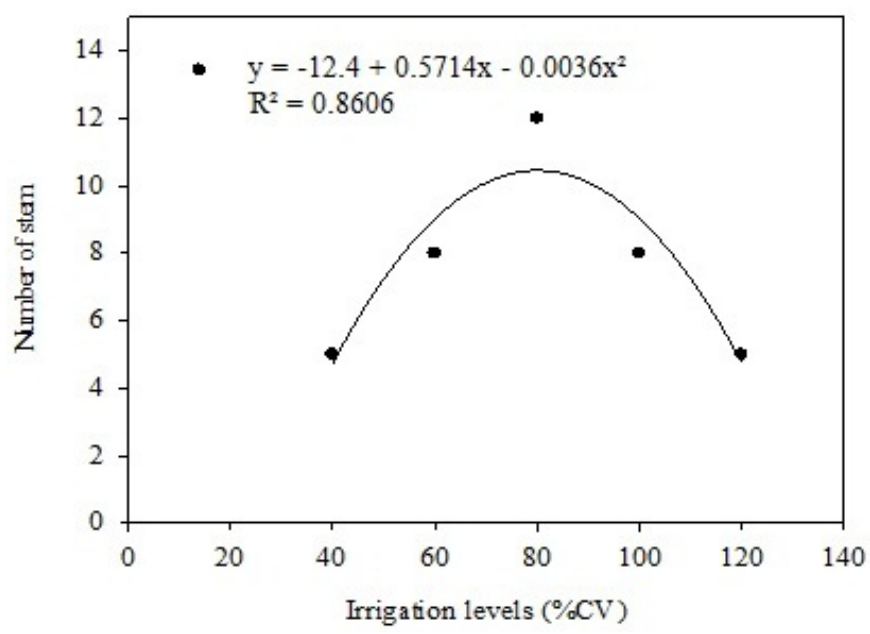

Figure 3. Number of floral stems throughout the gerbera crop cycle in the different irrigation levels. 
the plants to the different water availability $(30,45,60,75$, and $90 \%$ of WRC), and found that water moves more easily when the water conditions of the pot near the maximum retation capacity. This is related to the greater water availability to which it was submitted and does not prevent the transpiration by the plants and the evaporation of the water contained in the substrate, which results in superior water consumption. Thus, the hydraulic conductivity is lower in an unsaturated substrate because only a fraction of the substrate is occupied by water.

The best results regarding length, stem diameter and inflorescence were observed when the plants were in critical water conditions. Similar results were found for gladiolus by Pereira et al. (2009), who obtained satisfactory results of productivity and growth regarding stem length and number of flowers under conditions with no water deficit. Water excess or deficit can cause the elongation of the root system to restrict or increase the real availability of water in the soil. However, a reduction in shoot development occurs, interfering in its length and diameter, which significantly interferes in the stiffness of the stems, causing inflorescences outside the quality standard, especially under water deficit conditions.

When studying cravina crops and different irrigation levels, Schwab et al. (2013) observed that the water consumption with an availability of $100 \%$ WRC was much higher when compared to the other treatments, a result similar to the one found in the present study. These results can be explained by the greater availability of water, which increased the plantto-atmosphere exchanges, increasing plant tissues and plant development due to the absence of water factors that could cause stomata closure and, consequently, decrease in water consumption.

The lowest water consumption was observed at the lowest WRC levels. Furthermore, there was a reduction of the inflorescence diameter, stem height and diameter, and loss of petal coloration. However, when studying chrysanthemum, Farias et al. (2005) reported that the highest value of water consumption occurred with the lowest water stress in the soil but plants cultivated under these stress did not present the best development, corroborating with the results found in the present study.

The results obtained in this work can be compared with other crops, that relate to water deficit and excess for ornamental crops (Schwab et al., 2013; Girardi et al.,2016; Oliveira \& Gualtieri, 2017; Menegaes et al., 2019; Soares et al., 2019),

\section{Crop coefficient for cut gerbera}

As occurs with most ornamental species, the gerbera does not have a detailed phenological description with the distribution of its different phases during a production cycle. When searching for the crop coefficient, was created phenology from the treatment of $80 \%$ water availability, observing the behavior of the plants identified within the interval after the transplant of the gerbera seedlings.
There are in the literature some cultures of which the phenological phases have already been transcribed, for crops as sunflower (Cavalacante Junior et al., 2013), heliconia (Felisberto et al., 2015), melon (Lozano et al., 2017) and pepper (Lorenzoni et al., 2019). The crop coefficient is specific to each cultivar, varying according to the study location the conditions to which the crop was exposed. Thus, Table 3 presents a proposal for dividing the development of plants with the respective values of their crop coefficient $(\mathrm{Kc})$ according to the phenological phases determined for the present study, considering the Caribá cultivar obtained from the region of Santa Maria - RS.

When we determine the mean values of Kc for the different phenological phases of the crop, we obtained an average value of 0.76 in the vegetative phase and of 1.03 during the productive phase. Gomes et al. (2006) obtained average values of 0.88 and 1.23 for the vegetative and flowering (productive) phases, respectively, of Heliconia cultivated in a protected environment. The results found in the present study can be compared with those obtained by Gomes et al. (2008), who obtained mean values of 0.72 and 1.07 in the mentioned phases of the alpine culture. Oliveira et al. (2014) found mean values of crop coefficient equal to 0.75 and 1.18 for the rose (Carola cv) in the vegetative and productive development phases, respectively, cultivated under protected environment conditions in Minas Gerais.

In a study conducted with the alstroemeria culture in a protected environment, in the municipality of Santa Maria, RS, Girardi et al. (2016) created a phenology based on the treatment of $90 \%$ of WRC, finding average values of $0.39,0.41$, $0.95,1.50$, and 0.75 , in the vegetative phase, beginning of flowering, flowering, full flowering, and end of the flowering, respectively.

The crop coefficient values obtained in this study can be correlated with the differentiation of the water requirements during the phenological phases of gerbera in a protected environment, which have not yet been determined in other studies. Therefore, the need for researches regarding the development stages of the crop in question becomes relevant considering the climatological conditions of the region and emphasizing that the Kc values also change with the cultivar, irrigation system, ETo estimation method adopted, and the crop management.

Table 3. Days after transplant (DAT), development phases, crop coefficient $(\mathrm{Kc})$, reference evapotranspiration (Eto) for cut gerbera, cultivar Caribá. Santa Maria - RS, Brazil, 2017.

\begin{tabular}{cccc}
\hline $\begin{array}{c}\text { Days after transplant } \\
\text { (DAT) }\end{array}$ & Phases & Kc & Eto \\
\hline $0-29$ & Vegetative I & 0.72 & 2.91 \\
$29-58$ & Vegetative II & 0.81 & 2.92 \\
$58-87$ & Flowering I & 0.85 & 3.18 \\
$87-116$ & Full Flowering II & 0.89 & 3.22 \\
$116-145$ & Full Flowering III & 1.33 & 2.58 \\
$145-174$ & End of the Flowering I & 1.06 & 1.81 \\
\hline
\end{tabular}




\section{Conclusions}

The crop coefficients (Kc) proposed for the different phenological stages of the gerbera were efficient for irrigation management.

The water consumption for the cut gerbera crop in the treatments with limited water availability ranged from 225.87 to $523.58 \mathrm{~mm}$.

The crop coefficient $(\mathrm{Kc})$ determination for the conditions from the beginning to the end of cropping period of cut gerbera is important information for calcule of ETc and irrigation planning.

\section{Literature Cited}

Barbosa, B.D.S.; Oliveira, F.G.; De Figueiredo, E.P. Determinação do coeficiente de cultivo ( $\mathrm{kc}$ ) do Capim Tanzânia irrigado no norte de Minas Gerais. Revista Irriga, v.1, n.2, Edição Especial, Irriga \& Inovagri, p.11-20, 2015. https://doi.org/10.15809/ irriga.2015v1n2p11.

Bashandy, H.; Pietiäinen, M.; Carvalho, E.; Kean-jin, L.; Eloma, A.P.; Martens, S.; Teeri, T. Anthocyanin biosynthesis in gerbera cultivar 'Estelle' and its acyanic sport 'Ivory'. Planta, v.242, n.3, p.601611, 2015. https://doi.org/10.1007/s00425-015-2349-6.

Cardoso, J.C.; Imthurn, A.C.P. Easy and efficient chemical sterilization of the culture medium for in vitro growth of gerbera using chlorine dioxide ( $\mathrm{ClO} 2)$. Ornamental Horticulture, v.24, n.3, p.218-224, 2018. https://doi.org/10.14295/oh.v24i3.1222.

Carvalho, P.H. M.S.; Costa, W.R.S.; Silva, J. S. e.; Queiroz, S.O.P. de.; Souza, J.C. de. Desempenho agronômico de Gérbera sob reuso de água. Revista Brasileira de Agricultura Irrigada, v.12, n.6, p.3040-3047, 2018. https://doi.org/10.7127/RBAI.V12N600922.

Cattivello, C. Physicalproperties in commercial substrates and their relationships. Acta Horticulturae, v.294, p.207-214, 1991. https:// doi.org/10.17660/ActaHortic.1991.294.20.

Conover, C.A. Soil amendments for pot and field grown flowers. Florida Flower Grower, v.4, n.4, p.1-4, 1967.

Cavalcante Junior, E.G.; De Medeiros, J.F.; De Melo, T.K.; Sobrinho, J.E.; Bristot, G.; De Almeida, B.M. Necessidade hídrica da cultura do girassol irrigado na chapada do Apodi. Revista Brasileira de Engenharia Agricola e Ambiental, v.17, n.3, p.261-267, 2013. https://doi.org/10.1590/S1415-43662013000300003.

De Boodt, M.; Verdonck, O. The physical properties of the substrates in horticulture. Acta Horticulturae, v.26, p.37-44, 1972. https:// doi.org/10.17660/ActaHortic.1972.26.5.

De Souza Ferraz, R.L.; de Melo, A.S.; Suassuna, J.F.; de Brito, M.E.B.; Fernandes, P.D.; Júnior, E.D.S.N. Trocas gasosas e eficiência fotossintética em ecótipos de feijoeiro cultivados no semiárido. Pesquisa Agropecuária Tropical, v.42, n.2, 181-188, 2012. https:// doi.org/10.1590/S1983-40632012000200010.

Doorenbos, J.; Pruitt, W.O. Guidelines for predicting crop water requirements. Rome: $F A O, 1977.179 \mathrm{p}$.

Farias, M.F.; Saad, J.C.C. Crescimento e qualidade de crisântemo cultivado em vaso sob ambiente protegido. Horticultura Brasileira, v.23, n.3, p.740-742, 2005. https://doi.org/10.1590/ S0102-05362005000300010.
Felisberto, T.S.; Silva, D.O.; Souza Filho, J.R.; Santos, W.J.; Deon, M.D.; Marinho, L.B. Evapotranspiração e coeficiente de cultivo da helicônias Golden Torch no vale do são Francisco. Revista Brasileira de Agricultura Irrigada, v.9, n.5, p.335-343, 2015. https://doi.org/10.7127/rbai.v9n500331.

Fermino, M.H. Substratos: composição, caracterização e métodos de análise. Guaíba: Agro livros, 2014. 112 p.

Fermino, M.H; Kämpf, A.N. Densidade de substratos dependendo dos métodos de análise e níveis de umidade. Horticultura Brasileira, v.30, n.1, p.75-79, 2012. https://doi.org/10.1590/ S0102-05362012000100013.

Girardi, L.B.; Peiter, X.P.; Bellé, R.A.; Robaina A.D.; Torres R.R.; Kirchner, J.H.; Ben, L.H.B. Evapotranspiração e coeficiente de cultura da alstroemeria (Alstroemeria x hybrida) cultivada em estufa. Revista Irriga, v.21, n.4, p.817-829, 2016. https://doi. org/10.15809/irriga.2016v21n4p817-829.

Gomes, A.R.M.; D’Ávila, J.N.T.; Gondim, R.S.; Bezerra, F.C.; Bezerra, F.M.L. Estimativa da evapotranspiração e coeficiente de cultivo da Heliconia psittacorum L. $\times$ H. spathocircinada (Arist) cultivada em ambiente protegido. Revista Ciência Agronômica, v.37, p.1318, 2006. http://ccarevista.ufc.br/seer/index.php/ccarevista/ article/view/211. 02 Aug. 2019.

Gomes, A.R.M.; Gondim, R.S.; Bezerra, F.C.; Costa, C.A.G. Evapotranspiração e coeficientes de cultivo da Alpinia purpurata Revista Ciência Agronômica, v.39, p.481-486, 2008. http://www. ccarevista.ufc.br/seer/index.php/ccarevista/article/view/377. 02 Aug. 2019.

Holcman, E.; Sentelhas, P.C.; Mello, S.C. Microclimatic changes caused by different plastic coverings in greenhouses cultivated with cherry tomato in southern Brazil. Revista Brasileira de Meteorologia, v.30, n.2, p.125-133, 2015. https://doi. org/10.1590/0102-778620140094.

Kämpf, A.N.; Takane, R.J.; Siqueira, P.T.V. Floricultura: técnicas de preparo de substratos. Brasilia: LK, 2006. 129 p.

Landgraf, P.R.C.; Paiva, P.D. de O. Produção de flores cortadas no estado de Minas Gerais. Ciência e Agrotecnologia, v.33, n.1, p.120-126, 2009. https://doi.org/10.1590/S1413-70542009000100017.

Lorenzoni, M.Z.; Rezende, R.; Santos, F.A.; Souza, A.H. C. de.; Seron, C.C.; Nascimento, J.M.R. do. Estimation of the crop coefficient (kc) for bell pepper under greenhouse conditions. Revista Brasileira de Engenharia Agrícola e Ambiental, v.23, n.10, p.741-746, 2019. https://doi.org/10.1590/1807-1929/agriambi.v23n10p741-746.

Lozano, C.S.; Rezende, R.; Freitas, P.S.L. de; Hachmann, T.L.; Santos, F.A.S.; Andrean, A.F.B.A. Estimation of evapotranspiration and crop coefficient of melon cultivated in protected enviroment. Revista Brasileira de Engenharia Agrícola e Ambiental, v.21, n.11, p.758-762, 2017. https://doi.org/10.1590/1807-1929/agriambi. v21n11p758-762.

Ludwig, F.; Fernandes, D.M.; Guerrero, A.C.; Villas Boas, R.L. Laschi, D. Substratos no desenvolvimento de cultivares de gérbera envasada. Revista Brasileira de Horticultura Ornamental, v.21, n.2, p.177-184, 2015. https://doi.org/10.14295/aohl.v21i2.533.

Menegaes, J.; Backes, F.; Bellé, R.; Backes, R. Diagnóstico do mercado varejista de flores de Santa Maria, RS. Ornamental Horticulture, v.21, n.3, p.291-298, 2015. https://doi.org/10.14295/ oh.v21i3.629. 
Menegaes, J.F.; Bellé, R.A.; Swarowsky, A.; Backes, F.A.A.L.; Padrón, R.A.R. Consumo hídrico e desenvolvimento da cravina-chinesa cultivada em diferentes teores de Cu no solo. Acta Iguazu, v.8, n.1, p.76-91. 2019. http://saber.unioeste.br/index.php/actaiguazu/ article/view/19037/13938. 02 Aug. 2019.

Morales-Pérez, E.; Morales-Rosales, E.J.; Franco-Mora, O.; Pérez-López, D.J.; González-Huerta, A.; Sánchez, E.U. Producción de flores de Gerbera jamesonii cv. 'Dream'en función de los ácidos giberélico y salicílico. Фhyton, v.83, n.2, p.333-340, 2014. http://ppct.caicyt. gov.ar/index.php/phyton/article/view/8745/7762. 25 Aug. 2019.

Netto, D.H.; Carvalho, D.F.; Silva, L.D.B.; Guerra, J.G.M.; Ceddia, M.B. Evapotranspiração e coeficientes de cultivo da beterraba orgânica sob cobertura morta de leguminosa e gramínea. Horticultura Brasileira, v.29, n.3, p.330-334, 2011. https://doi.org/10.1590/ S0102-05362011000300012.

Oliveira, A.K.M. de; Gualtieri, S.C.J. Trocas gasosas e grau de tolerância ao estresse hídrico induzido em plantas jovens de Tabebuia aurea (paratudo) submetidas a alagamento. Ciência Florestal, v. 27, n.1, p.181-191, 2017. https://doi.org/10.5902/1980509826457.

Oliveira, G.M.; Leitão, M.V.B.R.; Bispo, R.C.; Santos, I.M.S.; Lima, C.B. de A.; de Carvalho, A.R.P. Coeficiente de cultura e produtividade da cebola submetida a diferentes lâminas de irrigação. Revista Brasileira de Engenharia Agrícola e Ambiental, v.17, n.9, p.969974, 2014. https://doi.org/10.1590/S1415-43662013000900009.

Pereira, J.R.D.; Carvalho, J.D.A.; Paiva, P.D.D.O.; Silva, D.J.D.; Souza, A.M.G.D.; Souza, K.J.D. Growth and production of gladiolus floral stems under different soil water tensions. Ciência e Agrotecnologia, v. 33, n. 4, p. 965-970, 2009. https://doi. org/10.1590/S1413-70542009000400004.

Ribeiro, M.S.; Silva, E.L.; Moura, D.C.M.; Dantas, A.A.A. Coeficiente de cultura (Kc) e crescimento vegetativo de acaiá cerrado associados a graus-dia e desenvolvimento. Irriga, v.14, n.2, p.220-232, 2009. https://doi.org/10.15809/irriga.2009v14n2p220-232.
Schafer, G.; Souza, P.V.D.; Fior, C.S. Um panorama das propriedades físicas e químicas de substratos utilizados em horticultura no sul do Brasil. Revista Brasileira de Horticultura Ornamental, v. 21, n.3, p. 299-306, 2015. https://doi.org/10.14295/oh.v21i3.735.

Schafer, G.; Souza, P.V.D.; Koller, O.C.; Schwarz, S.F. Physical and chemical properties of substrates to cultivate seedling of citrus rootstocks. Communications in Soil Science and Plant Analysis, v. 39, n.10, p. 1067-1079, 2008. https://doi. org/10.1080/00103620801925547.

Schmitz, J.A.K.; Souza, P.V.D.; Kampf, A.N. Propriedades químicas e físicas de substratos de origem mineral e orgânica para o cultivo de mudas em recipientes. Ciência Rural, v.32, n.6, p.937-944. 2002. https://doi.org/10.1590/S0103-84782002000600005

Schwab, N.T.; Peiter, M.X.; Bellé, R.A.; Backes, F.A.A. LConsumo hídrico de cravina submetida a diferentes estratégias de irrigação e tamanhos de vaso. Irriga, v.18, n.2, p.328-336, 2013. https:// doi.org/10.15809/irriga.2013v18n2p328.

Soares, F.C.; Netto, J.F.; Russi, J.L.; Duran,C.D.; Bortolás, F.A.; Lima, P.R. Water consumption, growth and development of cultivar dianthus chinensis I. Submitted to different doses of irrigation. Brazilian Journal of Development, v.5, n.6, p.6719-6728, 2019. https://doi.org/10.34117/bjdv5n6-165.

Sulzbach, M.; Ott, R.; Schafer, G.; Ott, A. P. Abundance and seasonality of two-spotted spider mite on gerbera cultivars.Ciência Rural, v.45, n.4, p.578-584, 2015. https://doi.org/10.1590/0103$8478 \mathrm{cr} 20131494$.

Verdonck, O.; Gabriels, R. Substrate requirements for plants. Acta Horticulturae, v. 221, p. 19-23, 1988. https://doi.org/10.17660/ ActaHortic.1988.221.1.

Zorzeto, T.Q.; Dechen, S.C.F.; Abreu, M.F.; Fernandes Júnior, F. Caracterização física de substratos para plantas. Bragantia, v.73, n.3, p.300-311, 2014. https://doi.org/10.1590/1678-4499.0086. 